Aim of the study: The aim of this work was to evaluate the knowledge of symptoms and prophylaxis among hospitalized patients.

Material and methods: The research was carried in the Provincial Hospital in Bydgoszcz (i.e. general surgery, gynecology and obstetrics, urology, breast surgery and thoracic surgery). 250 hospitalized patients took part in the tests, as well as 50 healthy people. The scientific method used was a specially designed questionnaire. The Bioethics Committee of Collegium Medicum of Mikołaj Kopernik University in Bydgoszcz approved these tests.

Results: Patients from the Breast Diseases Ward had better knowledge about cancers than the control group. Symptoms of lung cancer were known to both groups to the same extent. Patients from the Clinical Ward of Thoracic Surgery were very knowledgeable about lung cancer, but they did not know anything about other malignant types of cancer. Patients from Gynecology and Obstetrics wards are better than the control group only at knowledge about symptoms and screening of cervix cancer. Patients from the Urology Ward have the best knowledge about screening of prostate cancer and colon cancer. Those hospitalized at the Surgery Ward do not know symptoms of colon cancer, but they have knowledge about its screening.

Conclusions:

1. Patients from the Clinical Ward of Thoracic and Cancer Surgery and the Clinical Surgery Ward had the least knowledge about malignant tumors.

2. Patients from Urology, Gynecology and Obstetrics wards have better knowledge about malignant tumors treated there.

Key words: cancer, patient, knowledge, symptom, screening.

\section{Assessment of knowledge among patients of surgical wards regarding clinical symptoms and diagnostics of the most common malignant tumors}

\author{
Elżbieta Kozłowska, Maria T. Szewczyk
}

Department of Surgery Nursing, L. Rydygier Collegium Medicum in Bydgoszcz, Nicolaus Copernicus University in Torun, Poland Department and Clinic of General Surgery, L. Rydygier Collegium Medicum in Bydgoszcz, Nicolaus Copernicus University in Torun, Poland

\section{Introduction}

Cancer diseases are caused by the development and advancement of the modern world. In spite of development in the field of oncology the numbers of cases and deaths caused by cancer are still on the increase [1-7]. In 2005, 93060 deaths caused by malignant neoplasms were registered in Poland. Cases of death are at present much higher among men than women due to the high number of deaths in men linked to lung cancer. However, in recent years the situation has reversed because of decreasing figures in smoking men and increase in smoking women. The number of deaths caused by colon cancer and prostate cancer is increasing sharply, and figures in gastric cancer are diminishing. In the overall population of women included in this study the most common cause of death is breast cancer, yet in the last ten years the mortality rate has diminished slightly. At the same time the mortality rate due to lung cancer is growing in the aforementioned population, being the second most common cause of death. Compared to other countries Poland ranks high in cervical cancer mortality [8]. Lack of knowledge, skills and motivation prevents effective anti-cancer prophylaxis $[9,10]$. It is imperative to increase the health awareness in society, to improve the level of knowledge about symptoms and minimize fear of cancer, to point out possibilities of early diagnosis and effective treatment. Appropriate education and screening play a key role in reducing morbidity and mortality caused by malignant neoplasms [11-17].

\section{Aim of the study}

Assessment of knowledge in patients of surgical wards regarding clinical symptoms and the most common cancer screening tests.

\section{Material and methods}

The research was conducted in Jan Biziel Provincial Hospital in Bydgoszcz in the following wards: General Surgery Clinical Ward, Maternity Ward, Obstetrics and Gynecology, as well as Urology Ward; and also in the Oncology Centre in Bydgoszcz, in the Breast Diseases Ward and Clinical Ward of Thoracic and Cancer Surgery. Altogether taking part in the test were 300 people, including 250 patients of the aforementioned wards and 50 potentially healthy people selected from the employees of Solec Kujawski Town Hall as a control group. Surveyees were at different age. Average age of hospitalized patients was 50.5 years, and in the control group 43 years.

The research method was in the form of a questionnaire consisting of 8 open questions and 12 closed questions. The open questions were prepared 
in such a way as to establish the oncological awareness of people taking part in the test. Surveyees filled in the questionnaire independently, or, in the case of people in early stages of recuperation, with the help of a pollster. All the questionnaires were completed in the presence of the person conducting the test. The following was assumed: if at least one of the basic symptoms or methods of test screening was correctly mentioned by the patient, it would then be considered that the knowledge of symptoms and screening methods was adequate. The analysis of association was carried out by Pearson's linear correlation and values of $p<0.05$ were considered statistically significant. The Bioethics Committee of Collegium Medicum in Bydgoszcz, Nicolaus Copernicus University in Torun approved the studies.

\section{Results}

The knowledge of clinical symptoms and screening tests of the five most common cancers in Poland was analyzed. The results obtained from the hospitalized group were compared to those from the control group. It was found that patients from the Breast Diseases Ward and control group were equally aware of the symptoms of lung cancer. The knowledge about lung cancer symptoms is relatively extensive in both groups. The knowledge of clinical symptoms and screening tests of breast cancer is rather good ( $85 \%$ and $79 \%$ respectively). There were no statistically significant differences compared to the control group ( $p=0.40082$ and $p=0.461406$ respectively). In the group of people with cancer every other person knew the symptoms of colon cancer and this knowledge is statistically no different to that of the control group ( $p=0.687016$ ). However, the knowledge of colon cancer screening tests is statistically significantly higher in comparison to the control group ( $p=0.07093$ ). Among 50 people hospitalized at the Breast Diseases Ward less than half of subjects knew prostate cancer clinical symptoms. The knowledge of the screening test used for the disease is very low (9/50). The results are similar to those in the control group and the differences are statistically not significant. The knowledge of clinical symptoms and screening tests for early detection of cervical cancer among those hospitalized in Breast Diseases Ward is similar to the control group. Every other person knows clinical symptoms of the disease, but the knowledge of cervical cancer screening tests on offer is slightly higher in the control group. However, those differences are statistically not significant ( $p=0.841451$ and $p=0.108472$ ) (Table 1).

Among people treated in the Cancer and Thoracic Surgery Ward only every other patient knew basic clinical symptoms of lung cancer; the results were similar to the group of healthy people (27/50 and 31/50). In the analyzed group of 50 patients of the Thoracic and Cancer Surgery Ward, knowledge of clinical symptoms and screening tests for early detection of breast cancer is very low. Only $38 \%$ knew symptoms and $24 \%$ knew about the possibilities of early detection of the disease. Among healthy people the knowledge of those factors is quite good: $88 \%$ and $82 \%$. These differences are statistically significant $(p>0.005)$. More than $80 \%$ of people analyzed in the Thoracic and Cancer Surgery Ward did not know basic symptoms or measures used for early detection of colon cancer. Compared to the control group the level of knowledge of clinical symptoms is statistically significantly higher $(p=0.000430)$. The knowledge of screening tests is slightly higher in the control group but those differences are statistically not significant ( $p=0.118360)$. The majority of patients analyzed in the Thoracic and Cancer Surgery Ward knew neither cervical cancer symptoms nor screening tests suggested for early detection of the disease (84\% and 90\%). However, in the control group half of the surveyed people had knowledge about the aforementioned factors (48\% and 54\%). These differences are statistically significant ( $p=0.00145$ and $p=0.000061$ ) (Tables 2, 3).

In the analyzed group of women from the Obstetrics and Gynecology Ward every other patient had knowledge about symptoms of lung cancer. In the control group that knowledge is slightly higher (50\% vs. 62\%). Established differences are statistically not significant $(p=0.226774)$. The majority of patients of the ward are aware of breast cancer basic symptoms and screening tests applied for early detection of the disease (78\% and $74 \%$ respectively). Among healthy people a slightly higher percentage aware of the data was established (88\% and $82 \%$ respectively). These differences are statistically not significant ( $p=0.183170$ and $p=0.334247$ ).

The knowledge of colon cancer symptoms and screening tests for colon cancer in the analyzed group is low. Compared to the control group statistically significant differences were not found ( $p=0.229775)$. The knowledge of colon cancer and screening tests for its early detection is very low and statis-

Table 1. The knowledge of patients from the Breast Diseases Ward

\begin{tabular}{|c|c|c|c|c|c|}
\hline & Don't know & $\%$ & Know & $\%$ & $p$ \\
\hline lung cancer symptoms & 19 & 38 & 31 & 62 & \\
\hline breast cancer symptoms & 9 & 18 & 41 & 82 & 0.40082 \\
\hline breast cancer screening tests & 12 & 24 & 38 & 76 & 0.461406 \\
\hline colon cancer symptoms & 21 & 42 & 29 & 58 & 0.687016 \\
\hline colon cancer screening tests & 25 & 50 & 25 & 50 & 0.007093 \\
\hline prostate cancer symptoms & 28 & 56 & 22 & 44 & 0.839926 \\
\hline prostate cancer screening tests & 41 & 82 & 9 & 18 & 0.137090 \\
\hline cervical cancer symptoms & 25 & 50 & 25 & 50 & 0.841451 \\
\hline cervical cancer screening & 19 & 38 & 31 & 62 & 0.108472 \\
\hline
\end{tabular}


Table 2. The knowledge of patients from the Thoracic and Cancer Surgery Ward

\begin{tabular}{|c|c|c|c|c|c|}
\hline & Don't know & $\%$ & Know & $\%$ & $p$ \\
\hline lung cancer symptoms & 23 & 46 & 27 & 54 & 0.417693 \\
\hline breast cancer symptoms & 31 & 62 & 19 & 38 & $>0.005$ \\
\hline breast cancer screening tests & 38 & 76 & 12 & 24 & $>0.005$ \\
\hline colon cancer symptoms & 40 & 80 & 10 & 20 & 0.000430 \\
\hline colon cancer screening tests & 44 & 88 & 6 & 12 & 0.118360 \\
\hline prostate cancer symptoms & 43 & 86 & 7 & 14 & 0.001822 \\
\hline prostate cancer screening tests & 48 & 96 & 2 & 4 & 0.399709 \\
\hline cervical cancer symptoms & 42 & 84 & 8 & 16 & 0.000145 \\
\hline cervical cancer screening & 45 & 90 & 5 & 10 & 0.000061 \\
\hline
\end{tabular}

Table 3. The knowledge of patients from the Obstetrics and Gynecology Ward, also Oncological Gynecology

\begin{tabular}{|c|c|c|c|c|c|}
\hline & Don't know & $\%$ & Know & $\%$ & $p$ \\
\hline lung cancer symptoms & 25 & 50 & 25 & 50 & 0.226774 \\
\hline breast cancer symptoms & 11 & 22 & 39 & 78 & 0.183170 \\
\hline breast cancer screening tests & 13 & 26 & 37 & 74 & 0.334247 \\
\hline colon cancer symptoms & 29 & 58 & 21 & 42 & 0.229775 \\
\hline colon cancer screening tests & 35 & 70 & 15 & 30 & 0.499212 \\
\hline prostate cancer symptoms & 38 & 76 & 12 & 24 & 0.055626 \\
\hline prostate cancer screening tests & 42 & 84 & 8 & 16 & 0.218364 \\
\hline cervical cancer symptoms & 12 & 24 & 38 & 76 & 0.012424 \\
\hline cervical cancer screening & 13 & 26 & 37 & 74 & 0.004269 \\
\hline
\end{tabular}

Table 4. The knowledge of Urology Ward patients

\begin{tabular}{|c|c|c|c|c|c|}
\hline & Don't know & $\%$ & Know & $\%$ & $p$ \\
\hline lung cancer symptoms & 25 & 50 & 25 & 50 & 0.226774 \\
\hline breast cancer symptoms & 13 & 26 & 37 & 74 & 0.074377 \\
\hline breast cancer screening tests & 16 & 32 & 34 & 68 & 0.105979 \\
\hline colon cancer symptoms & 25 & 50 & 25 & 50 & 0.688923 \\
\hline colon cancer screening tests & 20 & 40 & 30 & 60 & 0.000266 \\
\hline prostate cancer symptoms & 29 & 58 & 21 & 42 & \\
\hline prostate cancer screening tests & 29 & 58 & 21 & 42 & 0.000087 \\
\hline cervical cancer symptoms & 29 & 58 & 21 & 42 & 0.316445 \\
\hline cervical cancer screening & 21 & 42 & 29 & 58 & 0.229775 \\
\hline
\end{tabular}

tically not different compared to the control group (24\% and $16 \%$ respectively). It was established that a relatively high percentage of women from the Gynecology and Obstetrics Ward knew cervical cancer symptoms and screening test principles. In the control group the level of awareness was considerably lower ( $52 \%$ and $46 \%$ respectively). The differences are statistically significant $(p=0.012424$ and $p=0.004269$ ) (Table 4).

Only half of the interviewees from the Urology Ward can list lung cancer symptoms.
The percentage of people from the control group knowing lung cancer symptoms is higher, but there is no statistical relationship ( $p=0.226774)$.

The level of knowledge of breast cancer symptoms and possibilities of screening tests is high (74\% and 68\% respectively); in the control group that level is slightly lower. The differences are statistically not significant ( $p=0.074377$ and $p=0.105979)$. Half of the patients treated in the Urology Ward recognize colon cancer symptoms and $60 \%$ know about possibilities of screening tests for colon cancer early detection. 
Compared to the control group the knowledge of symptoms and screening tests is higher, but the statistical relationship is only relevant for screening test knowledge $(p=0.000266)$. Symptoms of prostate cancer and screening test principles are known to only $42 \%$ of patients from the Urology Ward. The knowledge of symptoms is comparable to the control group, but the knowledge of screening test principles is statistically significantly higher $(p=0.000087)$. Among interviewees of the Urology Ward only $42 \%$ had knowledge of breast cancer symptoms and $58 \%$ knew the principles of the cervical cancer screening test. Compared to the control group no statistically significant differences were observed ( $p=0.316445)$ (Table 5).

The symptoms of lung cancer were not known to more than a half (56\%) of interviewees from the Clinical Surgery Ward. In the control group it was 38\%. A significant statistical difference was observed ( $p=0.71359)$. Symptoms of breast cancer as well as the principles of its screening tests are known to 24 interviewees (48\%) from the Clinical Surgery Ward. This knowledge is significantly higher in the control group ( $p=0.000018$ and $p=0.000366$ respectively). More than half of interviewees from the Clinical Surgery Ward did not have any knowledge considering colon cancer symptoms and its screening tests (66\% and 58\%). In the control group this percentage is significantly lower. A statistically significant difference in knowledge of clinical symptoms was observed
( $p=0.043959)$. Patients from the Surgery Ward did not know prostate cancer symptoms, nor the principles of screening tests. Out of 50 interviewed patients only 9 could list prostate cancer symptoms, while in the control group the symptoms were known to 21 people (42\%). The difference is statistically significant $(p=0.008833)$. The knowledge about cervical cancer symptoms and screening tests used for its early detection is very low among patients from the Clinical Surgery Ward. Only one in four patients knows its symptoms and one in five has knowledge about screening tests. The level of knowledge in the control group is much higher. These differences are statistically significant $(p=0.003925$ and $p=0.011307$ ) (Table 6).

\section{Analysis of results}

After cardiovascular diseases malignant neoplasm is the second most common cause of death. Half of those cases could be prevented through the combined efforts of society and the healthcare system. It turns out that most cases of cancer in Poland are detected in an advanced stage, which make the outcomes much less favorable. Mass screening tests form the basis for early prophylaxis [18]. In many cases early clinical symptoms could be observed even by an average person. Making society aware of the gravity of those undetected or neglected symptoms should relatively accelerate detection of disease [19-21]. 80\% of interviewees

Table 5. The knowledge of patients from the Clinical Surgery Ward

\begin{tabular}{|c|c|c|c|c|c|}
\hline & Don't know & $\%$ & Know & $\%$ & $p$ \\
\hline lung cancer symptoms & 28 & 56 & 22 & 44 & 0.071359 \\
\hline breast cancer symptoms & 26 & 52 & 24 & 48 & 0.000018 \\
\hline breast cancer screening tests & 26 & 52 & 24 & 48 & 0.000366 \\
\hline colon cancer symptoms & 33 & 66 & 17 & 34 & 0.043959 \\
\hline colon cancer screening tests & 29 & 58 & 21 & 42 & 0.055626 \\
\hline prostate cancer symptoms & 41 & 82 & 9 & 18 & 0.008833 \\
\hline prostate cancer screening tests & 42 & 84 & 8 & 16 & 0.218364 \\
\hline cervical cancer symptoms & 38 & 76 & 12 & 24 & 0.003925 \\
\hline cervical cancer screening & 39 & 78 & 11 & 22 & 0.011307 \\
\hline
\end{tabular}

Table 6. The knowledge of people from the control group

\begin{tabular}{|c|c|c|c|c|}
\hline & Don't know & $\%$ & Know & $\%$ \\
\hline lung cancer symptoms & 19 & 38 & 31 & 62 \\
\hline breast cancer symptoms & 6 & 12 & 44 & 88 \\
\hline breast cancer screening tests & 9 & 18 & 41 & 82 \\
\hline colon cancer symptoms & 23 & 46 & 27 & 54 \\
\hline colon cancer screening tests & 38 & 76 & 12 & 24 \\
\hline prostate cancer symptoms & 29 & 58 & 21 & 42 \\
\hline prostate cancer screening tests & 46 & 92 & 4 & 8 \\
\hline cervical cancer symptoms & 24 & 48 & 26 & 52 \\
\hline cervical cancer screening tests & 27 & 54 & 23 & 46 \\
\hline
\end{tabular}


among healthy people are aware of breast cancer clinical symptoms and possibilities of screening tests ( $88 \%$ and $82 \%$ respectively). This percentage is slightly lower in people treated in the Breast Diseases Ward, Obstetrics and Gynecology Ward and Urology Ward, but these differences are statistically insignificant. In the Thoracic and Cancer Surgery Ward and Clinical Surgery Ward the knowledge of both clinical symptoms and screening tests is considerably worse and statistically significant. It was observed that interviewees had the least knowledge about prostate cancer.

Awareness of clinical symptoms was very low in both hospitalized and healthy people. The least knowledge was observed among people treated in the Thoracic and Cancer Surgery Ward and Clinical Surgery Ward. These differences were statistically significant. Even fewer people were aware of the possibilities of early detection of prostate cancer; only patients from the Urology Ward showed undeniably better knowledge of screening tests (42\%) in comparison to healthy people [22]. Based on the analysis of knowledge regarding colon cancer symptoms and its screening tests, patients from the Thoracic and Cancer Surgery Ward have the least knowledge (20\% and $12 \%$ ) and those hospitalized in the Breast Diseases Ward and Urology Ward the most. In the Clinical Surgery Ward (where colon cancer patients are often treated) the knowledge of colon cancer clinical symptoms as well as screening tests applied in colon cancer is lower than that of patients from the Urology Ward and Breast Diseases Ward. Similar data were quoted by Pullyblank et al. In a study carried out in a group of 100 patients exposed to breast cancer and colon cancer screening tests it was observed that people treated due to colon cancer had better knowledge of breast cancer than of colon cancer [23].

The results are much better for the knowledge of cervical cancer symptoms and screening tests. The most knowledge is shown by patients from the Breast Diseases Ward, Obstetrics and Gynecology Ward and Urology Ward. Those hospitalized in the Clinical Surgery Ward and Thoracic and Cancer Surgery Ward have the least knowledge. In the group of healthy people (control group) 52\% are familiar with the subject of symptoms and $46 \%$ with the subject of screening tests. In a study carried out by Drosdzol et al. it was noted that only one in three students from Slask Medical Academy had adequate knowledge considering female organ neoplasms [24]. In 2000 Paul et al. conducted research among 700 people inhabiting Australia. The knowledge of screening tests was analyzed and the results were compared to those from 1989. The research confirmed that education conducted in the 1990s had a significant influence on raising health awareness [25]. It seems necessary to intensify promotion of societal awareness considering malignant neoplasms. According to Mayo et al. proper education is essential for screening tests to be effective [26]. Special attention should be paid to people living in rural areas, uneducated people, young people and those aged over 70 [27-32]. In educating women Hurd et al. applied unconventional methods regarding screening tests in malignant neoplasms, adjusted to perceived possibilities of a given group. By applying these methods they gained increased participation of women taking part by $79 \%$ [33]. In order to achieve a desirable change of behaviors and teach correct habits many years are required. Hence the educational process should be ongoing and long-term. The process should also continue during the patient's hospitalization.

In conclusions: Patients from the Thoracic and Cancer Surgery Ward have the least knowledge of all. Among people hospitalized in clinical wards where malignant neoplasms are treated it was observed that only patients from the Urology Ward and Obstetrics and Gynecology Ward had greater knowledge regarding neoplasms treated in those wards.

The authors declare no conflict of interest.

\section{References}

1. Wojciechowska U, Didkowska J, Tarkowski W, et al. Nowotwory złośliwe w Polsce w 2004 roku. Centrum Onkologii - Instytut im. Marii Skłodowskiej-Curie, Warszawa 2006.

2. De Vita VT, Hellman S, Rosenberg SA, et al. Cancer: principles practice of oncology. 7th Edition. Philadelphia 2005; 217-41.

3. Zegarski W, Mierzwa T. Przyczyny wzrostu występowania raka jelita grubego w Polsce. In: Interdyscyplinarny wymiar nauk o zdrowiu. Bartuzi Z (ed.). UMK CM, Bydgoszcz 2007; 505-8.

4. Jemal A, Siegel R, Ward E, Murray T, Xu J, Smigal C, Thun MJ. Cancer statistics, 2005. CA Cancer J Clin 2006; 56: 106-30.

5. Raporty na podstawie danych Centrum Onkologii. Available at: http://85.128.14.124/krn/ 20.03.2008.

6. Lubiński J. Nowotwory dziedziczne 2002 - profilaktyka, diagnostyka i leczenie. Termedia, Poznań 2002.

7. Nowicki A, Duda M, Kula Z. Wstępne wyniki programu badań przesiewowych dla wczesnego wykrywania raka jelita grubego realizowanego w Centrum Onkologii w Bydgoszczy w latach 2001-2004. Proktologia 2006; 7: 104-17.

8. Wojciechowska U, Didkowska J, Zatoński W. Nowotwory złośliwe w Polsce w 2008 roku. Centrum Onkologii - Instytut im. M. Skłodowskiej-Curie, Warszawa 2010.

9. Cebulska V, Koźlak V, Rzempowska J, Jerzyk-Rajbiś M. Poziom wiedzy i umiejętności kobiet w wieku średnim w zakresie dokonywania samooceny zdrowia. Hygeia Public Health 2011; 46: 372-5.

10. Celestino A, Castillo T, Frisancho O, Contardo C, Espejo H, Tomioka C, Navarrete J. Colorectal cancer: study on 365 cases. Rev Gastroenterol Peru 1996; 16: 187-96.

11. Hawley ST, Vernon SW, Levin B, Vallejo B. Prevalence of colorectal cancer screening in a large medical organization. Cancer Epidemiol Biomarkers Prev 2004; 13: 314-9.

12. Mierzwa T, Siwek P, Grabiec M. Badania profilaktyczne w kierunku raka piersi i szyjki macicy w Regionalnym Centrum Onkologii w Bydgoszczy w 2002 roku. Ginekol Pol 2003; 74: 811-6.

13. Banaszkiewicz Z, Szewczyk MT, Jarmocik P, et al. Metody skryningu raka jelita grubego. In: Interdyscyplinarny wymiar nauk o zdrowiu. Bartuzi Z (ed.). Bydgoszcz 2007; 22-6.

14. Gonciarz M, Reguła J, Mularczyk A. Rak jelita grubego-znaczenie badań przesiewowych. Nowa Klinika 2003; 10: 48-51.

15. Mierzwa T, Grabiec M, Walentowicz M. Ocena wyników badań profilaktycznych w kierunku raka szyjki macicy w Centrum Onkologii w Bydgoszczy w latach 2001-2006. In: Wybrane aspekty opieki zdrowotnej. Bartuzi Z (ed.). Bydgoszcz 2007; 298-302.

16. Wronkowski Z, Zwierko M. Zasady i wyniki programu modelowego skriningu raka piersi i raka szyjki macicy w Polsce 1999-2000. Nowotwory 2002; 52: 72-9.

17. Spaczyński M, Nowak-Markwitz E, Kędzia W. Skrining raka szyjki macicy w kraju i na świecie. Ginekol Pol 2007; 78: 354-60.

18. Jobda B. Programy przesiewowe. Magazyn Pielęgniarki i Położnej 2007; 11: 23.

19. Dobrzyń D, Starosolska H, Kołodziej W. Świadomość kobiet w zakresie profilaktyki chorób nowotworowych, Annales Universitatis Mariae Curie Skłodowska Lublin Sectio D, 2003; LVIII SuppI XIII 50: 272-6. 
20. Chojnacka-Szawłowska G. Wiedza o symptomach nowotworowych pacjentów poddawanych diagnostyce onkologicznej a stopień klinicznego zaawansowania choroby. Psychoonkologia 1998; 2: 27-36.

21. Cierzniakowska K, Szewczyk MT, Banaszkiewicz Z, Jawień A. Profesjonalna opieka nad osobą ze stomia w Polsce. Pielęg Chirur Angiol 2010; 2: 35-9.

22. Kozłowska E, Szewczyk MT, Banaszkiewicz Z, et al. Knowledge of symptoms and diagnostic possibilities of cancer diseases. Arch Med Sci 2011; 2: 304-9.

23. Pullyblank AM, Cawthorn SJ, Dixon AR. Knowledge of cancer symptoms among patients attending one-stop breast and rectal bleeding clinics. Eur J Surg Oncol 2002; 28: 511-5.

24. Drosdzol A, Nowosielski K, Skrzypulec V, et al. Świadomość onkologiczna studentek Śląskiej Akademii Medycznej dotycząca nowotworów żeńskich narządów płciowych. Ann Acad Med Siles 2005; 59: 359-62.

25. Paul C, Tzelepis F, Walsh RA, Girgis A, King L, McKenzie J. Has the investment in public cancer education delivered observable changes in knowledge over the past 10 years? Cancer 2003; 97: 2931-9.

26. Mayo RM, Sherrill WW, Crew L, Watt P, Mayo WW. Connecting rural African American and Hispanic women to cancer education and screening: the Avon Health Connector project. J Cancer Educ 2004; 19 123-6.

27. Podlińska MA, Bernacka M, Gotlib J. Próba oceny wpływu wieku na poziom wiedzy na temat raka szyjki macicy wśród pacjentek hospitalizowanych w oddziale położniczo-ginekologicznym. Pielęgniarstwo XXI wieku 2010; 1-2: 57-63.

28. Hurd TC, Muti P, Erwin DO, Womack S. An evaluation of the integration of non-traditional learning tools into a community based breast and cervical cancer education program: the Witness Project of Buffalo. BMC Cancer 2003; 3: 18.

29. Bannach M, Mierzwa T, Grabiec M, et al. Wpływ edukacji zdrowotnej na uczestnictwo kobiet ze środowisk wiejskich województwa kujawsko-pomorskiego w badaniach profilaktycznych. Ann Acad Med Siles 2005; 59: 4.

30. Koper A, Mierzwa T, Borzych B. Edukacja kobiet w zakresie profilaktyki raka piersi w województwie kujawsko-pomorskim. In: Wybrane aspekty opieki zdrowotnej. Bartuzi Z (ed.). Bydgoszcz 2007; 197-204.

31. Jokiel M, Bielska-Lasota M, Kraszewska E. Zmiany uświadomienia i zachowań zdrowotnych kobiet dotyczące profilaktyki raka szyjki macicy w latach 1976, 1986, 1990 i 1998. Prz Epidemiol 2001; 55: 323-30.

32. Mierzwa T, Koper A, Klatt I. Edukacja młodzieży szkół ponadgimnazjalnych w zakresie profilaktyki raka piersi w województwie kujawsko-pomorskim. In: Wybrane aspekty opieki zdrowotnej. Bartuzi Z (ed.). Bydgoszcz 2007; 303-8.

33. Hurd TC, Muti P, Erwin DO, Womack S. An evaluation of the integration of non-traditional learning tools into a community based breast and cervical cancer education program: the Witness Project of Buffalo. BMC Cancer 2003; 3: 18.

\section{Address for correspondence}

\section{Maria T. Szewczyk}

L. Rydygier Collegium Medicum

ul. Ujejskiego 75

85-168 Bydgoszcz

e-mail: mszewczyk@cm.umk.pl

Submitted: $\quad 4.04 .2012$

Accepted: $\quad 7.08 .2012$ 